\title{
LUBUK LARANGAN: BENTUK PERILAKU EKOLOGIS MASYARAKAT LOKAL DALAM PENGELOLAAN SUMBER DAYA PERIKANAN PERAIRAN UMUM DARATAN (TIPOLOGI SUNGAI)
}

\section{Lubuk Larangan: Form of Ecological Behavior of Local Community in The Inland Fisheries Resource Management (River Tipology)}

\author{
Nendah Kurniasari, Maharani Yulisti dan Christina Yuliaty \\ Balai Besar Penelitian Sosial Ekonomi Kelautan dan Perikanan \\ JI. KS. Tubun Petamburan VI Jakarta 10260 \\ Telp. (021) 53650162, Fax. (021)53650159 \\ Email: nendahkurniasari@gmail.com \\ Diterima 3 Mei 2013 - Disetujui 22 Nopember 2013
}

\begin{abstract}
ABSTRAK
Perilaku ekologis masyarakat di sekitar sungai merupakan sebuah modal mendasar bagi keberlangsungan sumberdaya ikan di kawasan sungai tersebut. Oleh karenanya, makalah ini bertujuan untuk menganalisis perilaku ekologis masyarakat lokal dalam memanfaatkan sumberdaya sungai. Penelitian dilaksanakan pada tahun 2012 pada masyarakat Nagari Manggilang Kecamatan Pangkalan Koto Baru Kabupaten Lima Puluh Kota Sumatera Barat yang menetap di daetah aliran sungai Batang Talagiri dan Batang Manggilang. Analisis data menggunakan analisis deskriptif kualitatif yang menginterpretasikan secara logic hubungan antara faktor-faktor pendorong, implementasi serta implikasi perilaku ekologis tersebut. Hasil penelitian menunjukkan bahwa Perilaku ekologis masyarakat Nagari Manggilang dalam memperlakukan sungai didukung oleh beberapa hal yaitu kondisi geografis, pola kepemimpinan, hukum adat, dan sistem mata pencaharian masyarat. Keempat unsur ini turut andil dalam melestarikan perilaku ekologis tersebut. Perilaku ekologis masyakat Manggilang yang terwujud dalam lubuk larangan tidak hanya berimplikasi terhadap perilaku ekologi masyarakat secara kolektif, juga merubah perilaku sosial ekonomi masyarakat ke arah yang lebih produktif dan memiliki nilai moral yang tinggi.
\end{abstract}

Kata Kunci: perilaku ekologis, lubuk larangan, sungai

\begin{abstract}
Ecological behavior is a potential capital of sustainable resources. This paper aims to study the ecological behavior of local communities in the use of river resources. This study was conducted in 2012 at Nagari Manggilang, Pangkalan Koto Baru, Lima Puluh Kota District, West Sumatera with the objects are the community who settled in the watershed of the Batang Talagiri river and Batang Manggilang river. Data analysed by using descriptive qualitative that interpreted logically the relation among the supportive factors, implementation factors, and the implication of the ecological behavior. The results showed that the ecological behavior of Nagari Manggilang' residents in treating the river suppoerted by several elements: geography, leadership patterns, customary laws, and livelihood systems. All of these elements contributed to preserve the ecological behavior. This ecological behavior at Nagari Manggilang' residents that materialized as "Lubuk Larangan" was not only implicated to the ecological behavior of the society, but also changed the social behavior as well as economic behavior towards a more productive society and higher morale values.
\end{abstract}

Keywords: ecological behavior, lubuk larangan, river 


\section{PENDAHULUAN}

Sumberdaya kelautan dan perikanan tidak hanya mempunyai nilai ekonomi tapi termasuk didalamnya nilai ekologi dan nilai sosial. Ketiga nilai ini saling terikat dan saling mempengaruhi dan turut andil dalam menciptakan perilaku manusia terhadap sumberdaya kelautan dan perikanan. Keberadaan sumberdaya sejatinya memang diperuntukkan untuk memenuhi kebutuhan hidup manusia. Namun, insting manusia yang cenderung mementingkan tujuan dan keinginan sesaat sering melahirkan perilaku yang lebih mementingkan nilai ekonomi ketimbang nilai ekologi dan nilai sosialnya. Padahal, dalam jangka waktu panjang, hilangnya salah satu nilai tersebut akan mengurangi nilai-nilai yang lain.

Kerusakan sumberdaya perikanan baik sumberdaya perikanan pesisir maupun sungai salah satunya diakibatkan oleh prilaku destruktif masyarakat baik dalam pemanfaat sumberdaya tersebut. Perilaku destruktif ini ditunjang oleh semakin majunya peradaban manusia dalam menciptakan teknologi yang dibungkus dengan kampanye modernisasi. Hilangnya beberapa species ikan di Sungai Brantas yang semula terdapat 17 species ikan air tawar pada tahun 2009 menjadi 11 species di tahun 2011 diindikasikan disebabkan oleh menurunnya kualitas air sungai dan berkurangnya habitat ideal bagi ikan (Anonymous, 2011). Lebih lanjut sumber dari harian tersebut mengatakan bahwa menurunnya kualitas air sungai menjadi penyebab utama berkurangnya jumlah habitat ideal bagi ikan, selain rusaknya fisik sungai.

Hal sama terjadi di Sungai Cisadane dan Sungai Ciliwung, Hadiaty1 (2010) mengungkapkan bahwa species ikan yang berada di DAS Ciliwung dari hulu sampai hilir sudah mulai punah. Dari 187 jumlah species yang tersisa kini hanya 15 species. Sedangkan di DAS Cisadane dari 135 jenis ikan yang ada kini hanya tinggal 38 jenis saja.

Kondisi ini diakibatkan oleh perilaku masyarakat pemanfaat sungai baik di daerah aliran sungai maupun yang jauh dari daerah aliran sungai seperti aktifitas penambangan pasir, pembuangan limbah industri dan rumah tangga, penggunaan alat tangkap ikan yang tidak ramah lingkungan, dll. Selain itu political will yang bias darat menyebabkan daerah aliran sungai tidak menjadi prioritas pembangunan.

Berdasarkan hal tersebut, maka terlihat bahwa menurunnya kualitas sumberdaya sungai disebabkan oleh perilaku masyarakat yang cenderung hanya mempertimbangkan kepentingan ekonomi terhadap sungai tersebut. Padahal, selain homo economicus, perlu disadari bahwa manusia pun secara fitrahnya merupakan homo socius dan homoecologicus. Perilaku yang mempertimbangkan keseimbangan antara pemenuhan kepentingan ekonomi, ekologi dan sosial merupakan hal yang penting agar pemanfaatan dan pengelolaan sumberdaya tidak hanya mampu mememuhi kebutuhan fisik, namun juga kebutuhan mental spiritual, baik untuk generasi sekarang maupun generasi yang akan datang.

Masyarakat di daerah aliran sungai di Sumatera Barat mempunyai mekanisme pengelolaan sumberdaya sungai yang mempertimbangkan ketiga hal tersebut. Pada awalnya orientasi pengelolaan mengarah pada pelestarian sumberdaya hayati sungai seperti perlindungan ikan dan ekosistem di sekitar sungai. Sehingga, masyarakat digiring untuk berprilaku ekologis terhadap sungai. Dalam perkembangannya, masyarakat tidak hanya mendapatkan keuntungan ekologis berupa bertambahnya populasi dan keragamanan ikan, namun mereka pun mendapatkan mata pencaharian alternatif baru sebagai penyedia jasa pariwisata, dan yang sangat penting adalah terjalinnya kohesifitas sosial yang semakin erat. Mekanisme pengelolaan sungai tersebut dikenal dengan nama "lubuk larangan".

Berdasarkan hal tersebut, penulisan makalah ini bertujuan untuk menganalisis perilaku ekologis masyarakat dalam mengelola dan memanfaatkan sungai dalam kelembagaan Lubuk Larangan. Analisis tersebut terkait dengan mengapa masyarakat berperilaku ekologis, implementasi perilaku ekologis, dan implikasi perilaku ekologis terhadap kehidupan masyarakat. Uraian ketiga sub bahasan tersebut diharapkan dapat menjadi bahan bagi upaya pemberdayaan masyarakat di sekitar daerah aliran sungai secara berkelanjutan.

${ }^{1}$ Peneliti LIPI, Disampaikan pada wartawan harian Pikiran Rakyat tanggal 13 Mei 2010,

yang dimuat dalam http;//www.pikiran-rakyat.com 


\section{METODOLOGI}

Penelitian dilaksanakan pada bulan Mei 2012 di Nagari Manggilang Kecamatan Pangkalan Koto Baru Kabupaten Lima Puluh Koto Provinsi Sumatera Barat. Data diambil melalui wawancara mendalam, observasi dan kaji literatur. Wawancara dilakukan terhadap informan yaitu masyarakat umum, tokoh adat (ninik mamak), tokoh pemuda, aparat pemerintahan Nagari Manggilang, pengurus Pokmaswas Manggilang Jaya Sakato, dan aparat Dinas Kelautan dan Perikanan Lima Puluh Kota. Sementara Observasi dilakukan terhadap lingkungan sekitar lubuk larangan baik lingkungan biotik maupun abiotik.

Data yang terkumpul kemudian dianalisis menggunakan analisis deskriptif kualitatif yang terdiri dari tiga tahapan yaitu reduksi data, display data, dan penarikan kesimpulan. Pada tahap reduksi data, data yang terkumpul dipilih sesuai dengan fokus kajian. Setelah itu dilakukan display data, yaitu mengelompokkan data berdasarkan sub-sub pembahasan yang kemudian disusun secara sistematis dan ditampilkan dalam sebuah matriks. Penampilan dalam sebuah matriks akan memudahkan untuk melihat hubungan antar sub pembahasan untuk kemudian ditarik sebuah kesimpulan.

\section{Perilaku Ekologis Masyarakat Manggilang dalam Sistem Lubuk Larangan}

Perilaku dalam Kamus Besar Bahasa Indonesia diartikan sebagai tanggapan atau reaksi individu terhadap rangsangan atau lingkungan. Perilaku ekologis adalah sebuah konsep yang berisi seperangkat nilai, norma, simbol, pengetahuan, pengalaman, aksi dan makna-makna yang kemudian membentuk tindakan manusia secara dinamis terhadap lingkungan fisik atau alam yang ada disekitarnya. Sementara itu, kata "Lubuk Larangan"secara terminologi berasal dari dua kata yaitu lubuk dan larangan. Lubuk mempunyai arti bagian yang dalam di sungai, sedangkan larangan adalah aturan yang melarang suatu perbuatan. Jadi, lubuk larangan adalah suatu kawasan yang berada di daerah aliran sungai yang dikelola oleh masyarakat melalui berbagai aturan baik formal maupun nonformal. Belum ada informasi yang valid kapan lubuk larangan mulai dilakukan oleh masyarakat namun saat ini tercatat terdapat ..... buah lubuk larangan di Kabupaten Lima Puluh Kota.
Lubuk larangan di Nagari Manggilang diberi nama "Manggilang Jaya Sakato" sesuai dengan nama Kelompok Masyarakat Pengawasnya yaitu Pokmaswas Manggilang Jaya Sakato (Pokmaswas Manjato). Pokmaswas merupakan sebuah lembaga yang dibentuk untuk mengawasi jalannya lubuk larangan tersebut. Pembentukan lubuk larangan melalui sebuah musyawarah warga yang terdiri dari berbagai unsur masyarakat diantaranya adalah tokoh adat, tokoh agama, tokoh pemuda, perwakilan tiap jorong, aparat pemerintahan nagari, dan unsur masyarakat lainnya.

Lubuk larangan dapat dikatakan sebagai aktualisasi perilaku ekologis masyarakat Nagari Manggilang. Implementasi perilaku ekologis tersebut dapat dilihat dari 4 hal yaitu 1). Kemampuan membagi wilayah pengelolaan berdasarkan kepentingan ekologi, ekonomi dan sosial, 2). Kemampuan melakukan pengambilan keputusan secara kolektif sehingga berimplikasi pada aspek psikis masyarakat untuk memiliki bersama dan mentaati setiap keputusan bersama, 3). Kemampuan membangun mekanisme penegakkan hukum yang efektif meminimalisir pelanggaran dan meredam konflik secara damai, dan 4). Kemampuan melakukan sosialisasi dengan baik sehingga tidak hanya masyarakat Nagari Manggilang yang mengetahui peraturan lubuk larangan, namun masyarakat di luar nagari pun mengetahui, menghargai dan ikut mentaati kesepakatan lokal tersebut.

\section{Zona ekologi, ekonomi dan sosial pada Lubuk Larangan}

Zonasi sungai yang masuk dalam lubuk larangan Manggilang Jaya Sakato di Nagari Manggilang memang belum memiliki batas-batas formal berupa keterangan tertulis di wilayah lubuk larangan, namun batas-batas alam sudah ditentukan dalam musyawarah warga dan tersosialisasi dengan baik sehingga masyarakat Nagari Manggilang dan masyarakat Nagari di sekitarnya sudah mengetahui dengan baik. Zonasi tersebut terbagi menjadi zona inti, zona penyangga dan zona pemanfaatan.

Pembagian zonasi pada lubuk larangan Manggilang tidak semata-mata hanya memperhatikan nilai ekologi dari sumberdaya sungai tapi juga nilai ekonomi dan nilai sosialnya. Zona inti yang mempunyai luas wilayah sekitar $6.000 \mathrm{~m}^{2}$ merupakan zona yang lebih banyak berfungsi sebagai zona ekologi karena zona ini 
merupakan zona konservasi (perlindungan dan pelestarian sumberdaya) yang diperuntukkan bagi perkembangbiakan ikan dan tidak boleh diganggu/ dimanfaatkan selama dalam masa pengelolaan lubuk larangan. Sementara Zona penyangga yang mempunyai luas wilayah kurang lebih $4.500 \mathrm{~m}^{2}$ merupakan zona pembatas antara zona inti dan pemanfaatan lebih ditujukan untuk memenuhi nilai ekonomi dan nilai sosial. Pada zona ini diberlakukan buka tutup lubuk dengan aturan yang disepakati bersama.

Nilai sosial tercermin jelas dalam mekanisme pengelolaan zona penyangga terutama ketika pelaksanaan buka lubuk. Mulai dari proses perencanaan, pelaksanaan, dan penutupan sarat akan semangat kebersamaan dengan menjunjung tinggi nilai-nilai solidaritas. Begitupun dalam penggunaan uang hasil pembukaan lubuk, diperuntukkan bagi pembangunan fasilitas-fasilitas sosial seperti masjid dan infrastruktur lainnya dan kegiatan-kegiatan sosial budaya misalnya penyelenggaraan acara adat perayaan idul fitri.

Zona pemanfaatan mempunyai luas wilayah $40.500 \mathrm{~m}^{2}$, mulai dari batas zona penyangga yaitu Muara Asahan sampai dengan pelompatan beruk di Batang Talagiri. Pada zona ini masyarakat dapat memanfaatkan sumberdaya sungai kapan saja namun dengan peralatan dan tatacara yang telah disepakati bersama. Pada zona ini mengakomodir kepentingan masyarakat untuk memanfaatkan sumberdaya sungai jika sewaktu-waktu mereka membutuhkannya.

Terbaginya sungai menjadi zona inti, zona penyangga dan zona pemanfaatan sesuai dengan Peraturan Pemerintah Nomor 60 Tahun 2007 tentang Konservasi Sumberdaya Ikan. Berdasarkan PP tersebut, lubuk larangan termasuk salah satu kawasan konservasi sumberdaya ikan yaitu upaya perlindungan, pelestarian dan pemanfaatan sumberdaya ikan, termasuk ekosistem, jenis dan genetik untuk menjamin keberadaan, ketersediaan dan kesinambungannya dengan tetap memelihara dan meningkatkan kualitas nilai dan keanekaragaman sumberdaya ikan. Jadi, perilaku ekologis masyarakat Manggilang dalam mengelola sungai tidak hanya dilindungi oleh aturan adat dan Keputusan Wali Nagari, namun dilindungi pula oleh Peraturan Pemerintah Republik Indonesia yang merupakan turunan dari Undang-Undang Nomor 31 Tahun 2004.

\section{Pengambilan Keputusan dalam Pelaksanaan Lubuk Larangan}

Selain mampu membuat zonasi atas pelaksanaan perilaku ekologisnya dengan sangat baik, masyarakat manggilang pun mampu membuat mekanisme pengambilan keputusan

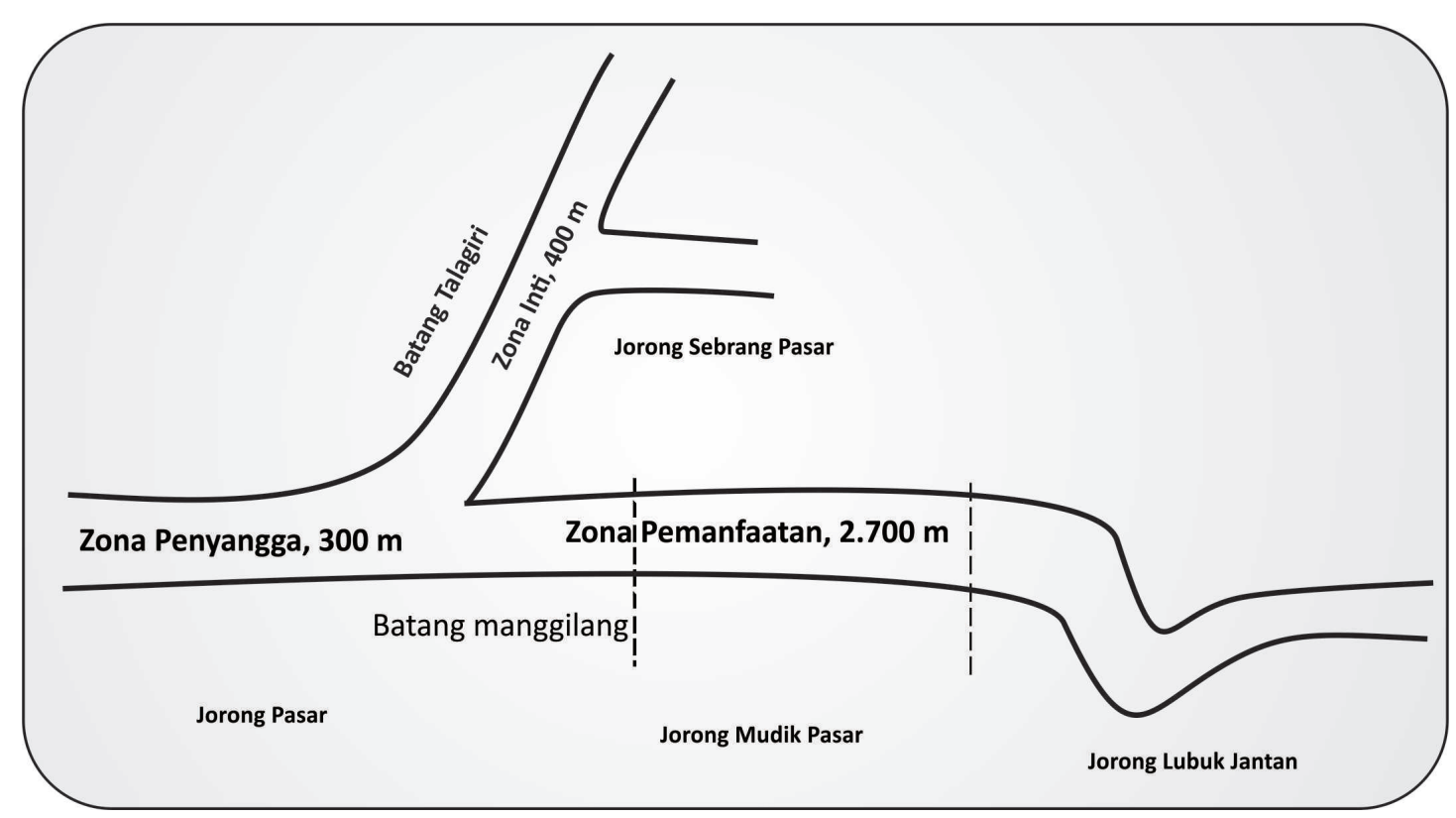

Gambar 1. Zonasi Lubuk Larangan Manggilang Jaya Sakato di Nagari Manggilang, Sumatera Barat. Figure 1. Zoning of Lubuk Larangan Manggilang Jaya Sakatoin Nagari Manggilang, West Sumatra. 
secara kolektif berdasarkan prinsip partisipatif dan representatif. Pengambilan keputusan ini terkait dengan mekanisme pengelolaan, mekanisme penegakkan aturan dan penentuan sanksi atas setiap pelanggaran yang terjadi. Keputusan kolektif yang pada dasarnya merupakan kesepakatan lokal ini merupakan pedoman dan payung hukum informal bagi perilaku ekologis masyarakat Manggilang.

Keputusan bersama dalam hal pengelolaan lubuk terkait dengan waktu buka tutup lubuk, aturan dalam buka tutup lubuk, distribusi hak, dan mekanisme pengawasan dan pemberian sanksi. Waktu buka tutup ditentukan yaitu pada saat menjelang Bulan Ramadhan. Sedangkan alat tangkap yang dijinkan adalah serok, pancing dan jala. Semua jenis ikan boleh diambil sepanjang ikan tersebut ada di zona penyangga dan zona pemanfaatan. Dengan dibatasinya jenis alat tangkap maka diharapkan ikan-ikan kecil tidak ikut terjaring. Peserta buka lubuk tidak hanya masyarakat lokal, masyarakat dari nagari tetangga pun dapat berpartisipasi. Hasil panen dimanfaatkan untuk pembangunan nagari seperti perbaikan jalan, mesjid dan mushala, kegiatan sosial, pendidikan, kegiatan pemuda dan pembelian benih ikan untuk restocking.

Mekanisme pengambilan keputusan secara kolektif pun dilakukan untuk menentukan distribusi hak pengelolaan dan pemanfaatan sumberdaya sungai. Distribusi hak tersebut terkait dengan hak mengakses, hak memanfaatkan, hak mengelola, dan hak memindahtangankan (Ostrom, 1990). Setiap orang, baik masyarakat Nagari Manggilang maupun masyarakat di luar nagari berhak mengkses sumberdaya sungai untuk berbagai kepentingan misalnya melintas dengan menggunakan perahu atau pun berenang sepanjang sungai tersebut, asalkan tidak mengambil ikan ataupun biota laut di dalamnya. Selama ini petani karet sering melintasi sungai ketika mengangkut hasil panennya atau pun menggunakan air sungai untuk merendam karet tersebut.

Sementara hak pemanfaatan sumberdaya sungai didasarkan pada zonasi yang telah dibuat. Pada zona pemanfaatan setiap warga Nagari Manggilang bisa mengambil ikan setiap saat, sementara masyarakat diluar nagari manggilang hanya diberi hak mengakses tanpa hak memanfatkan. Pada zona penyangga, semua masyarakat baik waraa nagari maupun diluar warga nagari diberi kesempatan untuk mengambil sumberdaya ikan pada masa buka lubuk dengan mekanisme yang telah diatur oleh panitia, sementara diluar masa itu tidak ada yang boleh mengambilnya. Pada zona inti semua warga tidak boleh memanfaatkan sumberdaya wilayah tersebut baik itu berupa ikan maupun biota lainnya. Zona inti benar-benar diperuntukan sebagai wilayah konservasi.

Hak pengelolaan lubuk larangan diserahkan kepada Pokmaswas yang beranggotakan setiap unsur masyarakat yaitu perwakilan dari nagari, para ninik mamak dari setiap suku, Bundo Kanduang, tokoh agama dan tokoh pemuda. Pengelolaan ini diantaranya terkait dengan penentuan dan mekanisme buka tutup lubuk, penetapan jenis sanksi atas setiap pelanggaran, serta berbagai kebijakan sesuai dengan kebutuhan dalam rangka mengembangkan lubuk agar lebih bermanfaat bagi masyarakat.

\section{Mekanisme Penegakkan Aturan dalam Lubuk Larangan}

Mekanisme pengambilan keputusan sangat berpengaruh terhadap keberlanjutan norma yang berlaku di dalam masyarakat. Begitupun normanorma yang berkaitan dengan pengelolaan lubuk larangan. Norma adalah aturan-aturan yang berisi petunjuk tingkah laku yang harus atau tidak boleh dilakukan manusia dan bersifat mengikat. Jadi perilaku ekologis masyarakat manggilang bukanlah perilaku yang bersifat individual, namun perilaku yang bersifat massal atau kolektif. Dalam ilmu psikologi sosial yang dilihat dari sudut pandang sosiologi, perilaku masyarakat bukanlah merupakan hasil atau agregat dari perilaku-perilaku individu, tapi perilaku individu dibentuk karena adanya norma-norma yang mengikat setiap individu untuk melakukan dan mentaati setiap norma yang disepakati bersama sehingga membentuk perilaku masyarakat.

Terdapat dua jenis aturan, pertama aturan yang tersurat yaitu aturan yang tertuang di dalam Keputusan Wali Nagari Manggilang No. 05 tahun 2006 tanggal 28 Juli 2006. Peraturan yang tersurat diataranya adalah jenis sanksi yang harus dikenakan jika terdapat pelanggaran yaitu adanya sanksi material dan sanksi sosial. Sanksi material berupa kewajiban memberikan semen sepuluh sak untuk setiap kilogram ikan yang diambil pada zona inti, sementara bila pelanggaran terjadi di zona penyangga maka pelanggar dikenakan denda tiga sak semen. Kedua adalah perturan yang 
tersirat, artinya perturan yang tidak tertulis dalam Keputusan Wali Nagari namun berlaku di dalam masyarakat. Salah satu contoh perturan yang tersirat tersebut adalah saksi yang dikenakan kepada tokoh masyarakat yang melakukan pelanggaran adalah sebesar dua kali lipat dari sanksi yang dikenakan kepada masyarakat umum. Jadi jika ada tokoh masyarakat baik itu aparat pemerintahan nagari, maupun tokoh adat yang melakukan pelanggaran maka dikenakan sanksi duapuluh sak semen untuk pelanggaran di zona inti dan enam sak semen untuk pelanggaran yang dilakukan di zona penyangga.

Perbedaan jenis sanksi kepada pelanggar yang berasal dari kalangan masyarakat umum dengan pelanggar yang berasal dari pemuka masyarakat pada pelaksanaan lubuk larangan di lubuk larangan Manggilang Jaya Sakato merupakan hal yang menarik dan tidak ditemukan di lubuk larangan yang lain. Hal ini menunjukkan bahwa masyarakat Nagari Manggilang masih menekankan bahwa moralitas merupakan prasyarat bagi setiap pemimpin. Bagi mereka, nilai moralitas pemimpin merupakan landasan perilaku kolektif masyarakat, karena pemimpin atau tokoh masyarakat merupakan panutan yang akan ditiru oleh masyarakatnya. Penetapan sanksi dilakukan oleh dewan adat yang terdiri dari unsur Kerapatan Adat Nagari (KAN), Wali Nagari, Bamus, Pemuda, Tokoh agama dan tokoh masyarakat.

Penegakan sanksi tersebut sangat ketat diawasi dan ditegakkan baik oleh pemerintahan nagari maupun lembaga adatnya. Jika si pelanggar belum melunasi sanksi yang dikenakan padanya maka pelanggar tersebut masih mempnyai utang adat dan akan dikenakan sanksi sosial berupa pengucilan dari masyarakat diantaranya adalah tidak dilibatkannya dalam acara-acara adat contohnya ketika ada kerabat yang akan melaksanakan kenduri maka ia tidak akan diundang. Dalam hal pemerintahan nagari, pelanggar yang masih mempunyai utang adat tidak akan dilayani kepentingannya terkait administrasi kependudukan di kenagarian misalnya tidak akan dibuatkan KTP atau surat ijin lainnya.

\section{Faktor Yang Mendukung Perilaku Ekologis dalam Sistem Lubuk Larangan}

Sebagai sebuah respon dari situasi di luar subjek tertentu, perilaku ekologis sebuah masyarakat dipengaruhi oleh situasi-situasi lingkungan di sekitanya. Oleh karenanya, mempelajari setting lingkungan merupakan hal mendasar dalam mempelajari kenapa suatu masyarakat mempunyai perilaku yang khas dalam memperlakukan alam. Salah satu aspek lingkungan yang berpengaruh adalah kondisi geografis. Kurnisari dan Reswati (2011) mengatakan bahwa setting geografis lingkungan akan memberi kesempatan mayarakat penghuninya untuk membuat peradaban guna memenuhi kebutuhan dan upaya mempertahankan diri. Veitch dan Arkkelin dalam literatur yang sama mengatakan bahwa dengan mengetahui setting tempat maka dapat diprediksi perilaku atau aktivitas yang terjadi. Setting lingkungan yang spesifik akan menyebabkan perbedaan pengetahuan seseorang dalam memaknai pengaruh lingkungan terhadap kehidupannya. Sementara itu, Winangun (2009) mengemukakan bahwa dengan pengetahuan manusia mengenali peristiwa dan permasalahan, menganalisa, mengurai, mengadakan interpretasi dan menentukan pilihan-pilihan. Begitu pun dalam fenomena lubuk larangan, seting geografis nagari memegang peranan penting dalam membentuk pengetahuan masyarakat untuk kemudian bertindak.

Nagari Manggilang adalah sebuah desa yang terletak di dataran tinggi Kabupaten Lima Puluh Kota Provinsi Sumatera Barat. Wilayah ini dialiri oleh sungai besar yaitu Batang ${ }^{2}$ Talagiri dan Batang Manggilang. Keterikatan masyarakat Manggilang terhadap sungai terlihat dari intensitas kegiatan mereka yang berhubungan dengan sungai. Mata pencaharian utama masyarakatnya adalah bertani dan berladang, dengan komoditas unggulannya adalah karet dan pinang. Umumnya kebun karet dan pinang terdapat di pegunungan, dan mereka memanfaatkan sungai untuk membawa hasil panennya ke pasar yang ada di wilayah yang lebih rendah.

${ }^{2}$ Batang adalah istilah lokal untuk sungai , batang talagiri berarti sungai yang bernama talagiri 
Sungai bagi masyarakat Manggilang tidak hanya sebagai sarana transportasi yang menunjang perekonomian mereka, namun sungaipun merupakan tempat kegiatan sosial. Bagi sebagian masyarakat, sungai digunakan untuk keperluan mandi dan mencuci, sehingga sungai pun merupakan tempat kegiatan sosial dimana anggota masyarakat terutama ibu-ibu saling berinteraksi dan anak-anak bermain dan berenang sambil tertawa riang. Mulyadi (2005) menyimpulkan risetnya tentang kehidupan masyarakat yang hidup bersama dengan sungai di Riau bahwa terikatnya kehidupan masyarakat terhadap sungai telah membentuk "budaya sungai". Hal ini dibuktikan pula oleh fakta sosial yang terjadi pada masyarakat Manggilang seperti diuraikan di atas. Budaya sungai Masyarakat Manggilang semakin terlembaga dengan baik semenjak dijadikannya wilayah sungai sebagai "Lubuk larangan". Jadi, Lubuk larangan bisa dikatakan sebagai salah satu contoh budaya sungai yang ada pada masyarakat Indonesia yang hidup di daerah aliran sungai.

Selain dipengaruhi oleh kondisi geografis, perilaku masyarakat dipengaruhi pula oleh latar belakang adat istiadat masyarakat tersebut.
Masyarakat Nagari Manggilang merupakan masyarakat adat. Masyarakat adat menurut Peraturan Menteri Negara Agraria/Kepala Badan Pertanahan Nasional Nomor 5 Tahun 1999, adalah sekelompok orang yang terikat oleh tatanan hukum adatnya sebagai warga bersama suatu persekutuan hukum karena kesamaan tempat tinggal atau pun atas dasar keturunan. Sementara Tania dalam Syahyuti (2012) lebih spesifik mendefinisikan masyarakat adat dilihat dari aspek aksesibilitasnya terhadap sumberdaya. Menurutnya, masyarakat adat adalah orang yang hidupnya tergantung pada sumber daya alam dan akses tersebut diperoleh secara adat atau kebiasaan. Dalam arti lain, masyarakat menentukan distribusi hak dalam pemanfaatan sumberdaya berdasarkan mekanisme adat yang dianutnya, bukan berdasarkan peraturan formal yang dibuat oleh pemerintah.

Besarnya peran adat dalam kehidupan masyarakat Manggilang merupakan indikasi bahwa kepimpinan yang dianut adalah "kepemimpinan tradisional". Meskipun kepemimpinan "rasionallegal" tetap ada dalam mengatur pengadministrasian pemerintahan nagari Manggilang, namun secara faktual kepemimpinan

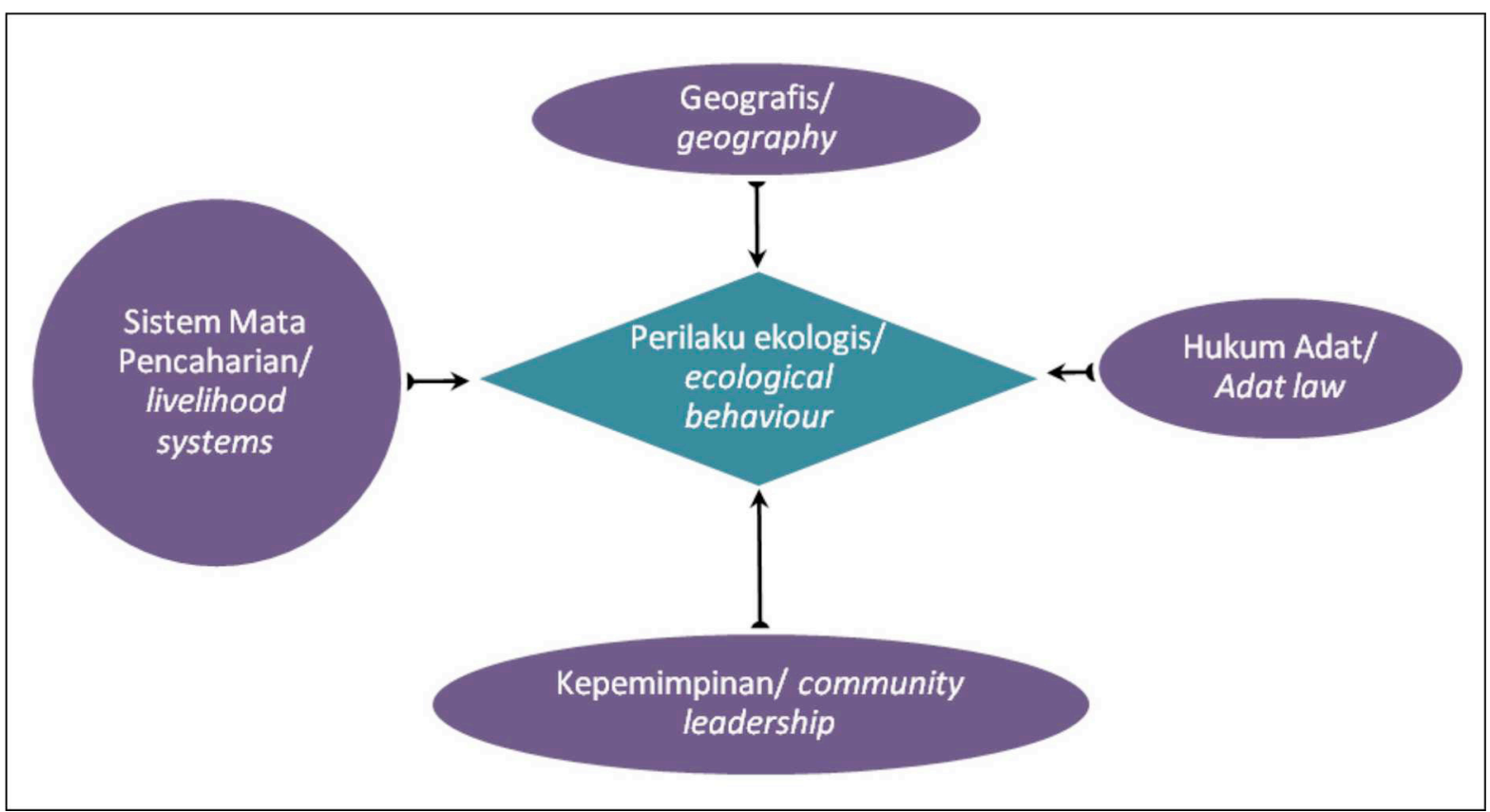

Gambar 2. Faktor-Faktor yang Mempengaruhi Perilaku Ekologis Masyarakat Nagari Manggilang, Sumatera Barat.

Figure 2. Factors That Influence the Ecological Behavior of Nagari Manggilang Society, West Sumatra.

Sumber: Data Primer Diolah, 2012 
tradisionallah yang dominan mengatur sistem sosial kemasyarakatan, sementara pemerintahan Nagari mengatur masalah administrasi pemerintahan. Kepemimpinan tradisional adalah orde sosial yang bersandar kepada kebiasaan-kebiasaan kuno yang mana status dan hak-hak pemimpin juga sangat ditentukan oleh adat kebiasaan (Fatimah, 2011). Kerukunan masyarakat Manggilang tidak terlepas dari peran ketua suku yang disebut ninik mamak. Kepatuhan masyarakat terhadap ninik mamak, menjadikan ninik mamak sebagai tokoh sentral dalam membentuk perilaku kolektif termasuk perilaku ekologis masyarakat dalam memanfaatkan sungai. Pada awal pendiriannya terdapat beberapa warga yang tidak setuju dengan kegiatan lubuk larangan karena mereka berpendapat bahwa sungai milik umum sehingga siapa pun dapat memanfaatkannya tanpa ditetapkan aturan yang mengikat. Namun, tokoh adat kemudian terus mengadakan sosialisasi akan pentingnya keberadaan lubuk larangan, sehingga masyarakat kemudian menyadari dan berperan serta dalam pengelolaan lubuk larangan (Kurniasari et al, 2012).

Terkait dengan perilaku ekologis masyarakat yang tercermin dalam kelembagaan lubuk larangan, terbaginya masyarakat kedalam suku-suku menjadikan pembinaan dan pengawasan menjadi lebih efektif. Ditinjau dari aspek psikologi, Sarwono (2005) mengatakan bahwa dalam kelompok yang lebih kecil setiap individu lebih bertanggungjawab, lebih efektif, dan lebih terikat pada kelompok, dan cenderung untuk tidak mengambil lebih dari apa yang diperlukan. Anggota suku cenderung akan mematuhi kesepakatan-kesepakatan kelompoknya, dan Ninik mamak dapat secara efektif membentuk perilaku masyarakat dan mengawasi perilaku anggotanya termasuk pelanggaran-pelanggaran terhadap kesepakatan-kesepakatan dalam pengelolaan lubuk larangan.

Kondisi lain yang mendukung terpeliharanya perilaku ekologis masyarakat Manggilang terhadap sungai adalah sistem mata pencaharian masyarakat yang tidak mengandalkan sumberdaya sungai. Oleh karenanya mereka tidak mengeksplorasi sumberdaya sungai untuk memenuhi kebutuhan hidup sehari-hari. Mereka umumnya merupakan petani yang memiliki areal pertanian di wilayah pegunungan. Mereka menjadikan sungai sebagai sarana penunjang aktivitas ekonomi yang mereka jalankan yaitu sebagai sarana transportasi untuk mengangkut hasil panen dari kebun ke pasar.
Jika dilihat dari sejarahnya, Inisiasi pembentukan lubuk larangan dilatarbelakangi oleh fakta yang dirasakan oleh sejumlah warga bahwa kondisi sungai semakin buruk dari tahun ke tahun baik kualitas airnya, maupun jenis ikan yang terdapat di perairan tersebut misalnya ikan kapiyek (puntius schwanefeldi) dan ikan garing (tor tambroides) yang dulu banyak semakin berkurang. Pembentukan lubuk larangan pun tidak terlepas dari karakter masyarakat Manggilang yang terbuka terhadap hal-hal yang bersifat positif. Menurut pengakuan salah satu tokoh masyarakat bahwa mereka mengadakan lubuk larangan ini setelah salah seorang tokoh masyarakat melihat keberhasilan lubuk larangan yang ada di Pasaman. Hal ini menunjukkan bahwa telah terjadi difusi kebudayaan dari Pasaman ke Manggilang. Difusi kebudayaan ini terjadi karena adanya kontak atau komunikasi antara pemuka masyarakat manggilang dengan pemuka masyarakat di Pasaman. Difusi budaya sungai -dalam hal ini adalah lubuk larangan- ini menjadi efektif berkembang di Manggilang karena pengaruh status inovator atau pembawa inovasi yaitu sebagai pemuka masyarakat. Tipe masyarakat Manggilang yang patuh terhadap pemimpinnya terutama pemimpin suku menyebabkan ide pendirian lubuk larangan mendapat sambutan masyarakat dan berkembang dengan baik.

Tidak hanya respon positif yang diberikan oleh masyarakat, pemerintah nagari pun menyambut baik dengan mengeluarkan Keputusan Wali Nagari Manggilang No 5 Tahun 2006 sebagai payung hukum pelaksanaan lubuk larangan di Manggilang. Hal ini sejalan dengan konsep yang diusung oleh Poerwanto (2000) bahwa dalam difusi kebudayaan dipengaruhi oleh peranan suatu kekuatan (power) dan aspek psikologis.

\section{Implikasi Perilaku Ekologis}

Lubuk larangan yang merupakan salah satu wujud perilaku ekologis masyarakat Manggilang, tidak hanya membawa implikasi pada berubahnya perilaku ekologi namun berkontribusi pula dalam mempertahankan perilaku sosial dan membangun perilaku ekonomi ke arah yang lebih produkstif. Implikasi terhadap perilaku ekologis yang dibawa oleh pelaksanaan lubuk larangan adalah berubahnya pemanfaatan sungai yang semula untuk kegiatan MCK (mandi cuci kakus) sekarang kegiatan tersebut berangsur-angsur 
menghilang. Saat ini sebagian besar masyarakat sudah mempunyai tempat MCK di rumah. Hal ini selain disebabkan oleh kesadaran mereka bahwa limbah kegiatan MCK akan mencemari sungai dan semakin bertambahnya jumlah ikan buntal yang dapat melukai mereka saat melakukan aktivitas MCK di sungai.

Implikasi terhadap perilaku sosial, diantaranya adalah berubahnya perilaku mudamudi dalam menyambut bulan Ramadhan. Sebelum diadakan lubuk, banyak kaum muda yang menyambut bulan Ramadhan dengan melakukan kegiatan yang dianggap tidak "elok dipandang" misalnya berkumpul mengadakan pesta atau bahkan berduaan dengan pasangan yang dianggap tidak sesuai dengan tradisi nenek moyang mereka. Setelah adanya lubuk yang dibuka menjelang bulan puasa, maka perilaku muda-mudi ini berubah karena mereka akan turut melakukan pembukaan lubuk dan bersuka ria bersama dengan seluruh warga. Hal ini pun turut merekatkan hubungan sosial diantara mereka.

Kaitannya dengan perilaku ekonomi, masyarakat ditantang untuk meningkatkan kreatifitasnya terhadap potensi ekonomi yang dapat diambil dari adanya lubuk larangan ini. Masyarakat yang semula hanya menggatungkan hidupnya dari produksi pertanian yaitu karet dan gambir, dengan adanya lubuk larangan bisa memanfaatkan waktu luang mereka sebelum panen dengan menyediakan layanan jasa pariwisata di sekitar lubuk larangan sehingga lebih produktif. Kegiatan ekonomi yang dapat mereka lakukan adalah penyewaan ban untuk berenang dan membuka warung-warung yang menyediakan makanan dan minuman ringan bagi pengunjung lubuk.

\section{KESIMPULAN DAN IMPLIKASI KEBIJAKAN}

Perilaku ekologis masyarakat Nagari Manggilang dalam memperlakukan sungai didukung oleh beberapa hal diantaranya adalah kondisi geografis, pola kepemimpinan, hukum adat, dan sistem mata pencaharian manyarakat. Keempat unsur ini turut andil dalam melestarikan perilaku ekologis tersebut. Perilaku ekologis masyakat Manggilang yang terwujud dalam lubuk larangan tidak hanya berimplikasi terhadap perilaku ekologi masyarakat secara kolektif, tetapi merimplikasi pula terhadap perilaku sosial ekonomi masyarakatnya.
Perubahan ini mengarah pada perubahan perilaku yang lebih membawa nilai positif yaitu lebih bermoral dan lebih produktif.

\section{DAFTAR PUSTAKA}

Anonymous. 2011. 6 Species Ikan di Sungai Brantas Hilang. http://regional.kompas. com/read/2011/07/18/21395570/6. Diakses Tanggal 16 Oktober 2013.

Fatimah, S. 2011. Kepemimpinan Tradisional Masyarakat Minangkabau pada Masa pendudukan Jepang. Jurnal Tingkap. Vol VII (1): $75-88$.

Kurniasari, N dan E. Reswati. 2011. Kearifan Lokal Masyarakat Lamalera: Sebuah Ekspresi Hubungan Manusia Dengan Laut. Buletin Riset Sosial Ekonomi Kelautan dan Perikanan. Vol 6 (2): 29 - 33.

Kurniasari, N., M. Yulisti, dan C. Yuliaty. 2012. Lubuk dan Kearifan Lokal Masyarakat Adat. Badan Penelitian dan Pengembangan Kelautan dan Perikanan dan Indonesian - Marine and Fisheries Socio-Economics Research Network. Jakarta.

Mulyadi, A. 2005. Hidup Bersama Sungai. Unri Press. Pekanbaru.

Ostrom, E. 1990. Governing The Commons: The evolution of institutions for collective action. Cambridge University Press.

Poerwanto, H. 2000. Kebudayaan dan Lingkungan Dalam Perspektif Antropologi. Pustaka Pelajar. Yogyakarta.

Republik Indonesia. 1999. Peraturan Menteri Negara Agraria/Kepala Badan Pertanahan Nasional Nomor 5 Tahun 1999 Tentang Pedoman Penyelesaian Masalah Hak Ulayat Masyarakat. Badan Pertanahan Nasional. Jakarta.

Sahyuti. 2012. Ciri-ciri Masyarakat Adat. http:// syahyutivariabel.blogspot.com/2012/07/ ciri-ciri-masyarakat-adat.html. Diakses tanggal 27 Desember 2012.

Sarwono, S.W. 2005. Psikologi Sosial: Psikologi Kelompok dan Psikologi Terapan. Balai Pustaka. Jakarta.

Winangun, J. 2009. Perilaku Masyarakat Dalam Motif Pemanfaatan Lahan Di Sekitar Jalan LingkarKota Demak. Tesis. Program Magister IImu Lingkungan Program Pascasarjana Universitas Diponegoro. Semarang. 